DOI: https://doi.org/10.18524/2519-2523.2021.16.245741

УДК 930.2(470+477)“18/19”

\title{
MUSEUM PUBLICATIONS OF THE SECOND HALF OF THE XIX - EARLY XX CENTURY IN THE RESEARCH OF NATIVE SCIENTISTS
}

\section{Nataliia Cherhik}

Post-graduate student of the

Zaporizhzhia National University, 66, Zhukovsky st., Zaporizhzhia, 69600, Ukraine

ORCID: https://orcid.org/00000003-4597-7184

E-mail: cherhik.n@gmail.com

Citation: Cherhik, N. (2021) Museum publications of the second half of the XIX - early XX century in the research of native scientists. Chornomors 'ka

Submitted: 12.10 .2021 mynuvshyna, vol. 16, pp. 74-79.

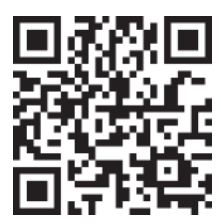

\section{Annotation}

The article presents publications of the late 19th-early 20th centuries, in which museum materials of Ukrainian origin are studied and published. This refers to museum catalogs, albums and reports. The purpose of this article is to trace the dynamics of the use of these publications in scientific research of colleagues during the late 19th-early 21th centuries. The proposed analysis proved the fact that museographic publications have acted an important role in scientific research for a long time, starting from the moment they were published until the present time. It was also found that as a historical source, museography was emphasized in three directions: the basis for conclusions about historical facts; the foundation for the protection of objects of history and museum research; and for museum attribution work. The context of the use of museum publications has changed. In the 19th century, they were used to show the development of museums in the south of the Russian Empire. In the Soviet period, "prerevolutionary" museum publications were perceived as traces of "bourgeois science." Modern researchers consider museum catalogs, albums, reports of the late 19th - early 20th centuries as one of the aspects of the manifestation of the process of national revival in Ukraine at the frontier of the century. It was also noted that at the end of the 19th and throughout the 20th century, publications of archaeological collections were more popular, especially materials found in the south of Ukraine. In the 21st century, the attention of researchers was attracted by materials from the period of the Cossacks. In general, there was a stable interest in Ukrainian museum publications of the late 19th-early 20th centuries.

Key words: museography, museum edition, historical source.

\section{МУЗЕЙНІ ВИДАННЯ ДРУГОӦ ПОЛОВИНИ ХІХ - ПОЧАТКУ ХХ СТОЛІТТЯ В ДОСЛІДЖЕННЯХ ВІТЧИЗНЯНИХ НАУКОВЦІВ}

\section{Наталія Чергік}

Аспірантка Запорізького національного університету, Вул. Жуковського, 66, м. Запоріжжя, 69600, Україна ORCID: https://orcid.org/0000-00034597-7184

E-mail: cherhik.n@gmail.com

\section{Анотація}

У роботі здійснено аналіз наукових публікацій вітчизняних авторів, які у другій половині XIX початку XX cm. увели до наукового обігу музейні матеріали українського походження. Запропонований огляд довів той факт, щуо музеографічні публікащіі відігравали важливу роль у наукових дослідженнях не тільки на момент їх виходу у світ, але й упродовж тривалого часу. Також було встановлено, шзо джерельне значення музеографії було акиентовано за трьома напрямами: обтрунтування висновків щзодо певних історичних фактів; підстава для пам'яткоохоронної діяльності та музеєзнавчих досліджень; музейна атрибуиія. 
Цитування: Чергік Н. Музейні видання другої половини XIX - початку XX століття в дослідженнях вітчизняних науковців. Чорноморська минувшина: записки Відділу історії козацтва на півдні України: зб. наук. пр. / за. ред. В.А. Смолія. Одеса: ФОП Бондаренко М.О., 2021. Вип. 16. С. 74-79.

Отримано: 12.10.2021 р.

Ключові слова: музеографія, музейне видання, історичне джерело.

У XIX ст. основний вектор наукової діяльності становила публікація історичних джерел та результатів досліджень, заснованих на аналізі документтів, археологічних артефактів, нематеріальних проявів національної культури. Один зі спектрів таких публікацій - музеографічні твори, які на українських теренах набули особливого поширення 3 другої половини ХІХ ст. В даній статті ми увагу звернули на те, наскільки активно і як саме музейні видання задіяні до досліджень вітчизняних науковців. Відповідь на поставлене питання дозволить виявити інформативний діапазон, тривалість та розвиток джерельного ефекту перших зразків української музейної публіцистики.

Об'єктом даного дослідження обрано наукові праці, до джерельної бази яких уведені українські музейні видання, що вийшли друком у Російській імперії наприкінці XIX - початку XX ст. i демонструють археологічні колекції та предмети доби козацтва приватних збірок $\mathrm{i}$ громадських музеїв. Предмет дослідження:динаміка застосування музеографічних публікацій у науково-дослідній роботі протягом кінця XIX - початку XXI ст.

Варто відзначити, що джерельна роль музейних видань стала предметом спеціального дослідження небагатьох авторів. Серед них можемо назвати I. В. Дворкіна [8], О. І. Кушпетюк [14], Л. Ю. Мельничук [18], Н. М. Товстоляк [27]. Огляд інформативної функції музейних видань у динаміці пропонується вперше.

Перед усім, заслуговує на увагу робота В. С. Іконнікова “Досвід російської історіографії”, в якій музеографія показана як один із засобів правильного розуміння загального перебігу історичних явищ. Автор назвав низку українських музейних видань, серед яких "Короткий покажчик" по музею Одеського товариства історії та старожитностей, складений М. Н. Мурзакевичем у 1873 р. В. С. Іконніков охарактеризував музейні твори як цілком наукові, наповнені необхідним матеріалом для полегшення користування джерелами, під якими автор розумів архівні документи та предмети колекцій - переважно монети, медалі, карти, археологічні знахідки [11, с. 23, 29-30, 302-303, 313, 323].

В такій функції музейні видання використані М. І. Петровим при укладанні четвертого і п’ятого випусків “Альбому старожитностей Церковно-археологічного музею при Імператорській Київській духовній академії”. Автор багаторазово скористався "Вказівником" цього ж музею, а також “Старожитностями Придніпров'я" та "Старожитностями Російськими” Богдана та Варвари Ханенків. Посилаючись на ці твори, М. І. Петров зробив аргументовані узагальнення відносно форм, видів та типів виробів скіфо-сарматської доби та слов'янського часу $[1$, c. $7,12,14,25-30]$.

Аналогічним шляхом Л. М. Кудь у дипломній роботі “Вбрання та прикраси давньоруської жінки”, для реконструкції типажу панянки періоду Київської Русі залучила п’ятий випуск альбому “Старожитності Придніпров'я”. Порівняння зразків колекції Київського міського музею $з$ опублікованими Ханенками зображеннями предметів їх колекції, стало підставою для висновків стосовно форм та технологій виготовлення прикрас [12, с. 8-14].

Ще один формат використання музеографічних творів кінця XIX - початку XX ст. уведення їх до джерельної бази досліджень стану пам'яткоохоронної діяльності та музейної справи в Україні. Наприклад, В.Б.Антонович використав факти, висвітлені у "Указателе выставки при III Археологическому съезде в Києве", для укладання "Археологической карты Киевской губернии” [5, с. 21, 31].

Низка музейних видань послужили джерелами написання статті “Музей” “Енциклопедичного словника Брокгауза та Ефрона”. Лаконічно надана інформація про українські музеї почерпнута переважно з музеографії артефактів півдня України та козацької 
доби - видань музею Імператорського Одеського товариства історії та старожитностей, Феодосійського музею старожитностей, каталогів старожитностей колекції В. В. Тарновського та О. М. Поля [19].

Більш розлогий “образ музейництва на Україні” надав I. С. Свенціцький в нарисі “Про музеї і музейництво”. Основну увагу автор приділив Київському міському музею (назвав фондоутворювачів, охарактеризував колекціі); інформацію про інші музеї подав стисло. Джерелами стали “Звіти” Київського Художньо-Промислового та наукового музею за 1910-1915 рр. та уже названі нами видання Церковно-Археологічного музею в Києві, Б. І та В. М. Ханенків, В. В. Тарновського, О. М. Поля [22].

Із досліджень другої половини ХХ ст. виділимо роботи А. М. Разгона “Археологічні музеї в Росії (1861-1917)" [20] та Л. М. Сак “З історії виникнення і розвитку Київського державного музею західного та східного мистецтва (1883-1945)" [21], в яких на підставі комплексу видань музею Одеського товариства історії та старожитностей, Феодосійського, Керченського, Херсонеського музеїв (А. М. Разгон) та серії альбомів Б. І. та В. М. Ханенків (Л. М. Сак) авторами встановлено шляхи поповнення збірок, принципи науково-дослідної, просвітницької, експозиційної роботи. Оскільки використані музеографічні джерела передували часу “глибокого засвоєння марксистсько-ленінської методології" [21, с. 400], авторами підкреслений вплив “оман” буржуазної науки [20, с. 198, 200, 204-205, 208] на зміст видань, музейну та археологічну практику.

Сьогодні науковці показують культурні зрушення в Україні в другій половині XIX початку XX ст. $з$ позиції процесів національного відродження. Певною мірою "регіональні” пам'яткоохоронні та музеєзнавчі студії базуються на “Звітах" музеїв. Наприклад, цей вид музеографічного твору використаний в роботах О. І. Кушпетюк [15; 16] та I. В. Кузьміної [13], присвячених розвитку музейної справи на Волині. Із залученням музейних “Звітів" досліджений розвиток археологічного музейництва на Чернігівщині та Полтавщині О. С. Черненко [28] і О. Б. Супруненком [26].

В сучасній музейній практиці музеографічні видання кінця XIX - початку XX ст. залучаються для наукової атрибуції колекцій. В якості прикладу наведемо масштабну атрибутивну роботу, побудовану на музеографії колекції В. В. Тарновського-молодшого, яку проводить Чернігівський історичний музей імені В. В. Тарновського. Спираючись на нові відомості про певний тип предметів, нові класифікаційні схеми щодо артефактів, новітні методи фізико-хімічного аналізу, залучивши іконографічні джерела - науковці музею поновили атрибуцію більшості раніше «закаталогізованих» предметів: уточнили датування, прочитали і вірно інтерпретували клейма і написи, визначили вміст дорогоцінних металів. Особливої уваги заслужила розкритикована свого часу М. С. Грушевським третя частина “Каталогу українських старожитностей В. В. Тарновського”, присвячена предметам козацької доби [7]. Важливо відзначити, що такими дослідженнями охоплено усі групи збірки Василя Тарновського. Колекцію срібного посуду, твори церковної металопластики, булави і перначі XVII-XVIII століття дослідила Г. П. Арендар [2; 3; 4]. Збірка артилерії переатрибутована М. М. Блакитним [6]. Колекція тканин стала предметом дослідження В. В. Зайченко [9; 10]. Унікальну колекцію стародруків, рукописів та документів дослідив I. М. Ситий [24; 25]. Атрибуцію шабель осучаснив А. С. Лаєвський [17]. Хрестам-енколпіонам приділила увагу Л. Ф. Сита [23]. Автори досліджень відзначили, що без “каталогів” XIX-XX ст. цю роботу не можна було б провести із таким успіхом, як це вдалося.

Проаналізовані публікації демонструють, що протягом другої половини XIX - початку XXI ст. науковці виявили і розробили такі галузі інформативного спрямування музеографії: історія, пам'яткознавство, музеєзнавство. Музейні публікації другої половини XIX - початку XX ст. "по свіжих слідах" використані переважно для виявлення аналогій та зроблених висновків щодо тенденцій розвитку матеріальної складової культурної спадщини України. При цьому увага дослідників була зосереджена переважно на публікаціях предметів релігійного змісту та археологічних знахідок, значний сегмент яких становили пам'ятки Причорномор'я та півдня України. В радянський період музейні видання служили основою для демонстрації втілення “буржуазних" концептів розвитку науки та музейної практики в 
Російській імперії. Сьогодні джерельна функція музеографії вийшла на якісно новий виток сучасні дослідники поновили атрибуції предметів музейних колекції, чим продемонстрували необхідність критичного підходу до раніше опублікованої музеографічної інформації. В цій царині поле зору дослідників поширилось на предмети козацької доби. Відбулися зміни у контексті використання музейних видань: сьогодні вони застосовані для демонстрації регіональних аспектів становлення музейної справи та археологічної науки в зв'язку із процесом національного відродження в Україні другої половині XIX - початку XX ст.

\section{Джерела та література:}

1. Альбом достопримечательностей Церковно-археологического музея при Императорской Киевской духовной академии / сост. Н. Петров. Киев : тип. С. В. Кульженко, 1915. Вып. 4-5. 62 с.

2. Арендар Г. П. Булави і перначі з колекції Василя Тарновського: питання атрибуції. Скарбниия української культури. Чернігів, 2013. Вип. 15. С. 177-182.

3. Арендар Г. П. Срібний посуд XVII-XVIII ст. з колекції В. В. Тарновського. Скарбниия украӥнської культури. Чернігів, 1996. Вип. 1 : Матеріали ювілейної наукової конференції, присвяченої 100-річчю Чернігівського історичного музею ім. В. В. Тарновського. С. 34-36.

4. Арендар Г. П. Церковні старожитності Василя Тарновського. Скарбниия української культури : зб. наук. пр. Чернігів, 2007. Вип. 8. С. 3-8.

5. Археологическая карта Киевской губернии / сост. В. Б. Антонович. М. : тип. М. Г. Волчанинова, 1895. 139, 20 с.

6. Блакитний М. М. Гармати 3 колекції Василя Тарновського в Чернігівському історичному музеї імені В. В. Тарновського. Скарбниия украӥнської культури. Чернігів, 2013. Вип. 15. С. 188-190.

7. Грушевський М. С. [Рецензія]. Записки Товариства імені Шевченка. Львів, 1901. Т. 40, кн. 2. С. 1-2. Рец. на кн.: Каталог украинских древностей коллекции В. В. Тарновского. Киев, 1898. Ст. $86+16$ табл., $4^{\circ}$.

8. Дворкін I. В. Джерела з історії музейної справи Наддніпрянської України XIX початку ХХ ст. Вісн. наи. техн. ун-ту «Харк. політехн. ін-т». 2013. № 25 (998). С. 17-22.

9. Зайченко В. В. Меморіальні ужиткові і декоративні тканини у зібранні В. В. Тарновського. Скарбниця української культури. Чернігів, 2013. Вип. 15. С. 191-194.

10. Зайченко В. В. Тканини $з$ колекції В. В. Тарновського у зібранні Чернігівського історичного музею ім. В. В. Тарновського (спроба віднайдення та атрибуції експонатів). Скарбниия української культури. Чернігів, 1996. Вип. 1 : Матеріали ювілейної наукової конференції, присвяченої 100-річчю Чернігівського історичного музею ім. В. В. Тарновського. C. 31-33.

11. Иконников В. С. Опыт русской историографии : в 2 т. Киев : тип. Императ. ун-та св. Владимира В. Завадскаго, 1891. Т. 1, кн. 1.882 с.

12. Кудь Л. Н. Костюм и украшения древнерусской женщины. Сб. Археол. музея Высш. жен. курсов в Киеве. Киев : тип. А. И. Гросмана, 1914. Вып. 2.51 с., VIII табл.

13. Кузьміна I. В. Українська гілка роду Штейнгелів: визначні постаті. Історикопросопографічне дослідження : дис канд. іст. наук : 07.00.06. Київ, 2016. 240 с.

14. Кушпетюк О. І. Звіти Городоцького музею барона Ф. Штейнгеля - джерело вивчення історії одного з перших музеїв Волинської губернії. 3б. навч.-метод. матеріалів $i$ наук. $\mathrm{cm}$. icm. фр-ту. Луцьк, 1998. Вип. 3. С. 77-79.

15. Кушпетюк О. І. Орест Левицький і волинське музейництво (до 170-річчя від дня народження). Емінак. 2018. № 1 (21) (січ.-берез.). С. 108-112.

16. Кушпетюк О. I. 150 років із часу заснування першого музею Волині. Наук. вісн. Східноєвроп. нац. ун-ту імені Лесі Украӥнки. Іст. науки. 2015. № 7. С. 156-161.

17. Лаєвський А. С. Шаблі XVII-XVIII століть 3 колекції Василя Тарновського в Чернігівському історичному музеї імені В.В.Тарновського. Скарбниия украӥнської культури. Чернігів, 2013. Вип. 15. С. 183-187. 
18. Мельничук Л. Ю. Друковані каталоги XIX - початку XX ст. як джерело дослідження мистецьких колекцій Харківського університету. Художня культура. Актуальні проблеми. 2009. Вип. 6. С. 605-615.

19. Музей. Энциклопедический словарь Брокгауза и Ефрона : в 86 т. / редкол.: К. К. Арсеньев, Ф. Ф. Петрушевский. СПб. : Семеновская тип. И. А. Ефрона, 1897. Т. 20. C. 112-126.

20. Разгон А. М. Археологические музеи России (1861-1917). Очерки истории музейного дела в России. М., 1961. Вып. 3. С. 190-230.

21. Сак Л. Н. Из истории возникновения и развития Киевского государственного музея западного и восточного искусства (1883-1945 гг.). Очерки истории музейного дела в СССР. М., 1963. Вып. 5. С. 373-405.

22. Свенціцький І. С. Про музеі і музейництво : нарисі і замітки. Львів : Діло, 1920. 79 с.

23. Сита Л. Ф. Хрести-енколпіони з колекції В. В. Тарновського у зібранні Чернігівського історичного музею. Скарбниия української культури. Чернігів, 2013. Вип. 15. С. 199-201.

24. Ситий I. М. Колекція стародруків музею українських старожитностей ім. В. В. Тарновського. Скарбниця української культури. Чернігів, 1996. Вип. 1 : Матеріали ювілейної наукової конференції, присвяченої 100-річчю Чернігівського історичного музею ім. В. В. Тарновського. С. 39-45.

25. Ситий I. М. Документальні матеріали в колекції В.В.Тарновського. Скарбниця украӥнської культури. Чернігів, 1996. Вип. 1 : Матеріали ювілейної наукової конференції, присвяченої 100-річчю Чернігівського історичного музею ім. В. В. Тарновського. С. 46-48.

26. Супруненко О. Б. Археологія в діяльності першого приватного музею України (Лубенський музей К.М.Скаржинської) : монографія. Київ-Полтава : Археологія, 2000. 392 с.: іл.

27. Товстоляк Н. М. Каталоги музею українських старожитностей В. В. Тарновського як джерела з історії Придніпров'я. Придніпров'я: історико-краєзнавчі дослідження. 2009. Вип. 7. C. $227-235$.

28. Черненко О. Є. Археологічна колекція Чернігівського історичного музею імені В. В. Тарновського (1896-1948рр.). Чернігів, 2007. 136 с.: іл. (Скарбниця української культури ; вип. 9 (Спецвип. 1)).

\section{References:}

1. Petrov, N. comp. (1915) Albom dostoprimechatelnostey Tserkovno-arkheologicheskogo muzeya pri Imperatorskoy Kievskoy dukhovnoy akademii. Kiev : tip. S. V. Kulzhenko Kiev: foto-litotipografiya S. V. Kul'zhenko, vol. IV-V. [in Russian].

2. Arendar, G.P. (2013) Bulavy i pernachi z kolektsii Vasylia Tarnovskoho: pytannia atrybutsii. Skarbnytsia ukrainskoi kultury, issue 15, pp. 177-182. [in Ukrainian].

3. Arendar, G. P. (1996) Sribnyj posud XVII-XVIII st. z kolektsii V. V. Tarnovskogo. Skarbnytsia ukrainskoi kultury, issue 1, pp. 34-36. [in Ukrainian].

4. Arendar, G. P. (2007) Tserkovni starozhytnosti Vasylia Tarnovskoho. Skarbnytsia ukrainskoi kultury, issue 8, pp. 3-8. [in Ukrainian].

5. Antonovich, V. B. (1895) Arheologicheskaya karta Kievskoj gubernii. Moskva: Tip. M. G. Volchaninova. [in Russian].

6. Blakytnyi, M. M. (2013) Garmaty z kolektsii Vasylia Tarnovskogo v Chernigivs`komu istorychnomu muzeiu imeni V. V. Tarnovskoho. Skarbnycia ukrainskoi kultury, issue 15, pp. 188190. [in Ukrainian].

7. Grushevskyi, M. S. (1901) [Retsenziia]. Katalog ukraynskykh drevnostei kollektsii V. V. Tarnovskoho, Kyiv, 1898, st. 86+16 tabl., 4. Zapy`sky` tovary`stva imeni Shevchenka, vol. 40, kn. 2, pp. 1-2. [in Ukrainian].

8. Dvorkin, I. V. (2013) Dzherela z istorii muzeinoi spravy Naddniprianskoi Ukrainy XIX pochatku XX st. Visnyk Natsionalnoho tekhnichnoho universytetu «Kharkivskyi politekhnichnyi instytut», no. 25 (998), pp. 17-22. [in Ukrainian]. 
9. Zaichenko, V. V. (2013) Memorialni uzhytkovi i dekoratyvni tkanyny u zibranni V.V.Tarnovskoho. Skarbnytiya ukrainskoi kultury, issue 15, pp. 191-194. [in Ukrainian].

10. Zaichenko, V. V. (1996) Tkanyny z kolektsii V. V. Tarnovskoho u zibranni Chernihivskoho istorychnogo muzeiu im. V. V. Tarnovskoho (sproba vidnaidennia ta atrybutsii eksponativ). Skarbnytsia ukrayinskoi kultury, issue, 1, pp. 31-133. [in Ukrainian].

11. Ikonnikov, V. S. (1891) Opyt russkoy istoriografii. Kiev: Tipografiya Imperatorskogo universiteta sv. Vladimira V. Zavadskago, vol. 1. [in Russian].

12. Kud', L. N. (1914) Kostyum i ukrasheniya drevnerusskoy zhenshchiny. Sbornik Arkheologicheskogo muzeya Vyshikh zhenskikh kursov v Kieve, vol. 2. Kiev: Tipografiya

A. I. Grosmana. [in Russian].

13. Kuzmina, I. V. (2016) Ukrainska gilka rodu Shteinheliv: vyznachni postati. Istorykoprosopografichne doslidzhennia. Ph.D. Thesis. Kyiv: Natsionalna akademiia nauk Ukrainy, Instytut istorii Ukrainy. [in Ukrainian].

14. Kushpetiuk, O. I. (1998) Zvity Gorodockoho muzeiu barona F.Shteinhelia - dzherelo vyvchennia istorii odnoho z pershykh muzeiv Volynskoi gubernii. Zbirnyk navchalno-metodychnykh materialiv i naukovykh statei istorychnoho fakultetu, issue 3, pp. 77-79. [in Ukrainian].

15. Kushpetiuk, O. I. (2018) Orest Levytskyi i volynske muzeinytstvo (do 170-richchia vid dnia narodzhennia). Eminak, no. 1 (21), pp. 108-112. [in Ukrainian].

16. Kushpetiuk, O. I. (2015) 150 rokiv iz chasu zasnuvannia pershoho muzeiu Volyni. Naukovyi visnyk Skhidnoievropeiskoho natsionalnoho universytetu imeni Lesi Ukrainky. Istorychni nauky, no. 7, pp. 156-161. [in Ukrainian].

17. Laievskyi, A. S. (2013) Shabli XVII-XVIII stolit z kolektsii Vasylya Tarnovskoho v Chernihivskomu istorychnomu muzeiu imeni V. V. Tarnovskoho. Skarbnytsia ukrainskoi kultury, issue 15, pp. 183-187. [in Ukrainian].

18. Melnychuk, L. Yu. (2009) Drukovani katalogy XIX - pochatku XX st. iak dzherelo doslidzhennia mysteckykh kolektsii Kharkivskoho universytetu. Khudozhnia kultura. Aktualni problemy, no. 6, pp. 605-615. [in Ukrainian].

19. Arsenev, K. K. red., (1897) Muzei. In: Ehnciklopedicheskii slovar' Brokgauza i Efrona. Sankt-Peterburg: Semenovskaya Tipolitografiya I. A. Efrona, vol. 20, pp. 112-126. [in Russian].

20. Razgon, A. M. (1961) Arkheologicheskie muzei Rossii (1861-1917). Ocherki istorii muzejnogo dela $v$ Rossii, issue 3, pp. 190-230. [in Russian].

21. Sak, L. N. (1963) Iz istorii vozniknoveniya i razvitiya Kievskogo gosudarstvennogo muzeya zapadnogo i vostochnogo iskusstva (1883-1945 gg.). In: Ocherki istorii muzejnogo dela v SSSR, issue 5, pp. 373-405. [in Russian].

22. Sventsitskyi, I. S. (1920). Pro muzei i muzeinytstvo: narysy i zamitky. Lviv: Dilo. [in Ukrainian].

23. Syta, L. F. (2013) Khresty-enkolpiony z kolektsii V. V. Tarnovskoho u zibranni Chernihivskoho istorychnoho muzeiu. Skarbnytsia ukrainskoi kultury, issue 15, pp. 199-201. [in Ukrainian].

24. Sytyi, I. M. (1996) Kolektsiia starodrukiv muzeiu ukrayinskykh starozhytnostei im.V.V.Tarnovskoho. Skarbnytsya ukrainskoi kultury, issue 1, pp. 39-45. [in Ukrainian].

25. Sytyi, I. M. (1996) Dokumentalni materialy v kolektsii V. V. Tarnovskoho. Skarbnytsia ukrainskoi kultury, vol. 1, pp. 46-48. [in Ukrainian].

26. Suprunenko, O. B. (2000) Arkheolohiia v diialnosti pershoho pryvatnoho muzeiu Ukrainy (Lubenskyi muzei K. M. Skarzhynskoi). Kyiv; Poltava: Arkheolohiia. [in Ukrainian].

27. Tovstoliak, N. M. (2009) Katalohy muzeiu ukrainskykh starozhytnostei V. V. Tarnovskoho iak dzherela $\mathrm{z}$ istorii Prydniprovia. Prydniprovia: istoryko-kraieznavchi doslidzhennia, issue 7, pp. 227-235. [in Ukrainian].

28. Chernenko, O. Ye. (2007) Arkheolohichna kolektsiia Chernihivskoho istorychnoho muzeiu imeni V. V. Tarnovskoho (1896-1948 rr.). Skarbnytsia ukrainskoi kultury, issue 9, pp. 1-136. [in Ukrainian]. 